(C) О.М. Спірін, С.М. Іванова, О.В. Новицький, М.А. Шиненко, 2010 ISSN 2076-8184. Інформаційні технології і засоби навчання. 2010. №6 (20).

Режим доступу до журналу: http://www.ime.edu-ua.net/em.html

УДК 002.2-028.27:02](477)

Спірін Олег Михайлович, доктор педагогічних наук, головний науковий співробітник, Інститут інформаційних технологій і засобів навчання НАПН України, м. Київ

Іванова Світлана Миколаївна, науковий співробітник Інституту інформаційних технологій і засобів навчання НАПН України, м. Київ

Новицький Олександр Вадимович, науковий співробітник, Інститут інформаційних технологій і засобів навчання НАПН України, м. Київ

Шиненко Микола Андрійович, науковий співробітник, Інститут інформаційних технологій і засобів навчання НАПН України, м. Київ

\title{
ПРОЕКТ КОНЦЕПЦІЇ ЕЛЕКТРОННОЇ БІБЛІОТЕКИ НАЦІОНАЛЬНОЇ АКАДЕМІЇ ПЕДАГОГІЧНИХ НАУК УКРАЇНИ
}

\begin{abstract}
Анотація
У Концепції обгрунтовується актуальність створення електронної бібліотеки
\end{abstract} (ЕБ) НАПН України, даються визначення основних понять i термінів, які використовуються в дослідженні, описуються основні напрями формування i розвитку електронної бібліотеки (ЕБ) НАПН України. Сформульовано цілі, принципи, завдання, функції ЕБ. Визначаються загальні передумови проектування ЕБ НАПН України, надаються орієнтовні вихідні дані. Визначено класифікацію інформаційних ресурсів для ЕБ НАПН України й етапи їх формування. Описаний процес управління інформаційними ресурсами й адміністрування ЕБ. Положення Концепції $\epsilon$ основою для розробки профілю іiі комплектування, визначення пріоритетів у доборі видань для переведення в електронну форму, вирішення технологічних проблем.

Ключові слова: електронна бібліотека, Інтернет, інформаційні ресурси, інформаційні і комунікаційні технології.

\section{Вступ}

У двадцять першому столітті, у процесі перехідного періоду від інформаційного суспільства до суспільства знань, у який увійшла Україна, важливим завданням постає створення мережевого розподіленого середовища для забезпечення 
доступу до ресурсів бібліотек, архівів, музеїв та інших інформаційних систем у сфері науки й освіти [10]. Одним із пріоритетів розвитку інформаційного суспільства в Україні є забезпечення вільного доступу до даних. Бібліотеки, що відносяться до різних галузей та відомств, є важливими компонентами інформаційно-ресурсного забезпечення сучасного суспільного розвитку.

У наукових установах і навчальних закладах НАПН України функціонують бібліотеки, що переважно використовують традиційні технології. Необхідність підвищення ефективності інформаційного забезпечення наукової й освітньої діяльності, інтеграції освіти та науки в науково-світовий інформаційний простір вимагають, а розвиток інформаційно-комунікаційних технологій (IКТ) дозволяє, суттєво вдосконалити бібліотечну діяльність на основі застосування електронних бібліотек та розподілених бібліотечних інформаційних мереж.

Роботи 3 розвитку електронних бібліотек i формування інформаційних наукових і освітніх ресурсів передбачені в Посланні Президента України Віктора Януковича до Українського народу [7], Розпорядженні Кабінету Міністрів України «Про схвалення Концепції Державної цільової програми розвитку професійнотехнічної освіти на 2011-2015 роки» [9], Державною програмою «Інформаційні та комунікаційні технології в освіті і науці» на 2006-2010 рр., Законом України «Про Національну програму інформатизації» (2001р.), указами Президента України «Про заходи щодо розвитку національної складової глобальної інформаційної мережі Інтернет та забезпечення широкого доступу до цієї мережі в Україні» (2000р.), Концепцією Державної цільової національно-культурної програми створення єдиної інформаційної бібліотечної системи «Бібліотека — XXI» (2009р.).

Упровадження електронної бібліотеки дозволить значно підвищити ефективність наукових досліджень й організації навчального процесу, оскільки забезпечить вільний доступ до ресурсів між навчальними і науковими закладами НАПН України. Буде вирішена проблема забезпечення навчального процесу якісними навчальними посібниками та додатковою літературою. Усі заклади, наукові установи НАПН України будуть об'єднані протоколом обміну метаінформацією, що вирішить низку проблем з обміну досвідом проведення і впровадження новітніх технологій навчання і наукових досліджень.

\section{ОСНОВНІ ПОНЯТТЯ}


Електронна бібліотека - розподілена інформаційна система, що дозволяє накопичувати, надійно зберігати й ефективно використовувати різноманітні колекції електронних повнотекстових документів, які доступні в зручному для користувача вигляді через глобальні мережі передавання даних.

Електронні джерела - електронні версії книжок, журналів, авторефератів, карт, малюнків, наукових видань, періодичних видань, дисертацій, довідників, словників, енциклопедичних видань, монографій, посібників, підручників, а також бази даних, мапи, карти користувача тощо.

Електронний документ - сукупність даних у пам'яті комп'ютера чи на зовнішньому електронному носії інформації, призначена для сприйняття людиною за допомогою відповідних програмних і апаратних засобів. Електронний документ може включати текстову, графічну, аудіо- чи відеоінформацію, мати лінійну чи нелінійну структуру.

Електронний інформаційний ресурс - інформаційний ресурс, що зберігається в електронному форматі i може бути знайдений та перетворений засобами електронної мережі або іншої електронної технології опрацювання даних (наприклад, CD-ROM).

Електронний каталог - перелік наявних джерел бібліотеки, що міститься на сайті бібліотеки. Сайт може пропонувати множину електронних каталогів, а також містити каталоги (або посилання на каталоги) джерел інших бібліотек, баз даних чи організацій [6].

Електронна колекція - систематизована сукупність інформаційних ресурсів в електронних бібліотеках, що об’єднані стосовно певного формального критерію належності, наприклад, стосовно спільності змісту, джерел, призначення, кола користувачів, способу доступу.

Електронна копія документа, електронний еквівалент документа електронний документ, отриманий шляхом оцифрування - (перетворення в електронну форму) - документа на традиційних носіях (папір тощо).

Електронні фонди - перелік та короткий опис (основа фонду, джерела поповнення, науково-культурне значення, найцінніші зібрання) фондів бібліотеки, що містяться на їі сайті. Зміст фондів, зазвичай, упорядкований за авторами та алфавітом. 
Інформаційний ресурс - сукупність документів у інформаційних системах (бібліотеках, архівах, банках даних тощо) [8].

Інформаційно-бібліотечний ресурс - інформаційний ресурс автоматизованих бібліотечних систем.

Інформаційно-бібліотечний сервіс - сервіс, притаманний функціонуванню бібліотечних систем.

Інтегрований електронний каталог - каталог, що містить зведену інформацію кількох електронних каталогів різних бібліотек.

Інформаційна система - організаційно впорядкована сукупність документів (масивів документів) й інформаційних технологій, зокрема, з використанням засобів обчислювальної техніки і зв'язку, що реалізують інформаційні процеси. Інформаційні системи призначені для зберігання, обробки, пошуку, розповсюдження, передання та надання інформації [5].

Метадані (метаінформація) - дані про дані. Формалізований опис колекції, документа чи ресурсу. Поряд із цим під метаданими розуміються структуровані відомості про електронний ресурс, що представляють його властивості (чи атрибути). Вони включають інформацію, що описує різні аспекти фактичних елементів даних, наприклад, ім'я, формат, вміст.

Ресурс - є все, що має ідентифікатор. Наприклад, документи, електронні об'яви, колекції ресурсів.

Сервіс - система, що забезпечує одну чи декілька функцій, що мають цінність для кінцевого користувача. Прикладами є фотокопіювання, банківський сервіс, міжбібліотечний обмін, web-сервіс.

\section{МЕТА І ЗАВДАННЯ СТВОРЕННЯ}

Головною метою створення електронної бібліотеки Національної академії педагогічних наук України (ЕБ НАПН України) $є$ забезпечення користувачів Інтернету доступом до науково-освітніх, електронних інформаційних ресурсів Академії.

Основні завдання:

1) Досягнення якісно нового рівня, повноти й оперативності задоволення інформаційних потреб науковців НАПН України за рахунок використання нових інформаційних технологій з метою підвищення якості наукових досліджень. 
2) Підвищення ефективності використання наявних наукових інформаційних ресурсів НАПН України за рахунок створення якісно нового інформаційного середовища.

3) Найбільш ефективне використання можливостей сучасних інформаційних технологій.

4) Оперативне інформування наукової громадськості про результати наукової діяльності в НАПН України.

5) Координація наукової діяльності організацій НАПН України в організації інформаційного обслуговування співробітників НАПН України.

6) Більш ефективне використання ресурсів і засобів, що виділяються НАПН України на наукові дослідження.

7) Входження наукової громадськості НАПН України у світову інформаційну громадськість і світовий інформаційний ринок.

8) Збереження і подальший розвиток наукових зв'язків з ученими світу.

9) Оперативне і найбільш повне інформування наукової громадськості світу про наукові дослідження і розробки в закладах та установах НАПН України.

\section{ОСНОВНІ ПРИНЦИПИ}

Багатофункціональність. ЕБ НАПН України, як джерело відомостей, має розв'язувати різні науково-освітні завдання, зокрема:

- інформаційні. Для задоволення потреби щодо різноманітних наукових відомостей та даних наукових співробітників НАПН України й інших наукових і навчальних закладів України і світу;

- наукові. Спрямовані на сприяння в проведенні наукових досліджень науковцями і фахівцями за рахунок надання широких наукових відомостей;

- освітні. Для підтримки підвищення освітнього рівня шляхом надання доступу до відповідних матеріалів;

- довідкові. Надання різних наукових довідкових матеріалів, включаючи автореферати, підручники, монографії, довідники і т. д.;

- просвітницькі. Для популяризації вітчизняних наукових досягнень, презентації наукових установ і науковців;

- фондостворюючі. Для забезпечення збереження наукового фонду України. 
Цілісність. Передбачає створення цілісної самодостатньої ресурсної структури як складової інформаційної системи НАПН України.

Численність науково-освітніх відомостей ЕБ НАПН України повинна містити численні різноманітні науково-освітні відомості. Насамперед, до них відносяться: періодичні видання, препринти, наукові статті, монографії, реферати дисертацій і тексти дисертацій, звіти про науково-дослідну роботу, науково-довідкова інформація тощо. Перелік не є фіксованим і повинен легко розширюватися в ЕБ. Хронологічні рамки для документів, що включаються в ЕБ, не встановлюються.

Централізованість. Інформаційні ресурси повинні організовуватися за принципом централізованої бази даних. Це означає, що будь-які інформаційні ресурси будуть зберігатися централізовано.

Принцип відкритих систем. Створення середовища, що містить програмні, апаратні засоби, служби зв'язку, інтерфейси, формати даних та протоколи, які у своїй основі мають доступні та загальновизнані стандарти, що забезпечують переносимість, взаємодію і масштабованіть застосувань та даних [1, 3].

Демократичність. Забезпечення рівних можливостей користувачів ЕБ НАПН України для отримання відомостей і даних.

Відповідність сучасному рівню розвитку інформаційно-комунікаційних технологій. Основні проектні рішення створення ЕБ НАПН України грунтуються на використанні сучасного програмного забезпечення Eprints, операційної системи Linux, засадах технології Web.

Доступність. ЕБ НАПН України повинна бути максимально доступною для вчених і освітян. Інформаційні ресурси за можливості повинні бути максимально відкритими для їхнього використання.

Розвиненість пошукових засобів. Відмінною рисою ЕБ НАПН України $є$ можливість одночасного використання різних пошукових механізмів i засобів доступу до вітчизняних баз електронних документів. Пошукові засоби повинні бути організовані так, щоб їхні можливості були прозорими щодо розподілу інформаційних ресурсів за різними сайтами і базами даних та можливої неоднорідності форматів даних. Мають підтримувати різні механізми інформаційного пошуку. Пошукова мова повинна мати достатню повноту для знаходження адекватних інформаційних ресурсів. Не менш важливим є вирішення проблеми 
подання різнорідних відомостей $\mathrm{i}$ даних у зручному вигляді для кінцевого користувача.

Розвиток співробітництва. Встановлення нових зв'язків 3 науковцями, педагогами, освітніми і науковими установами й організаціями з метою накопичення $\mathrm{i}$ передавання професійного досвіду і набуття знань [8].

Функціональна стандартизація. Особлива увага під час створення електронної бібліотеки приділяється узгодженню використовуваних стандартів 3 урахуванням прийнятих міжнародних стандартів з організації і ведення електронних бібліотек [4].

Правове i нормативне забезпечення. Буде розроблена нормативна база функціонування НЕБ НАНУ, зокрема, у тому числі сформульовані пропозиції 3 удосконалювання діючих чи прийняттю нових нормативних актів НАПНУ. Мають бути визначені порядок взаємодії різних категорій учасників НЕБ, їхні права та обов'язки, вирішені питання авторського права й інших форм інтелектуальної власності. Повинен бути розроблений комплекс організаційних, нормативнотехнічних документів, що регламентують створення і використання НЕБ, а також фінансових аспектів їх функціонування.

\section{ВИХІДНІ ДАНІ ДЛЯ ПРОЕКТУВАННЯ ЕБ НАПН УКРАЇНИ}

Проектування ЕБ технологічно й організаційно об'єднує бібліотечні комплекси наукових установ і навчальних закладів НАПН України, тому має свої особливості й відмінності.

Нинішній стан бібліотек наукових установ та навчальних закладів визначають вихідні дані для проектування ЕБ НАПН України, зокрема:

1. Наявність розподіленої системи електронних каталогів та інформаційних ресурсів власної генерації, сформованих під управлінням кількох різних автоматизованих бібліотечно-інформаційних систем (АБІС) i представлених в Інтернеті у вигляді бібліотечних сайтів.

2. Нерівномірний розвиток рівня надання доступу до електронних ресурсів у бібліотеках.

3. Бібліографічні інформаційні ресурси й електронні документи зберігаються розподілено в файлових системах комп'ютерів бібліотек. 
4. Наявність великої кількості онлайнових інформаційних ресурсів різної тематичної спрямованості, одержуваних 3 Інтернету. Постачальники ресурсів не пов'язані єдиною пошуковою системою, а на сайтах бібліотек іноді подаються у вигляді списку.

5. Весь навчально-методичний комплекс дисциплін навчальних закладів НАПН України - багаторівневих і багатозв'язних електронних документів, необхідних для впровадження сучасних технологій навчання, зокрема дистанційного, не організований в єдиний інформаційний ресурс, доступ 3 Інтернету до нього ускладнений або іноді відсутній.

6. Відсутність доступу до повнотекстових ресурсів, які продукуються в установах академії, що призводить до низьких рівнів індекс-цитувань статей, особливо зарубіжними авторами. Ця проблема виникає внаслідок відсутності середовища, до якого такі ресурси можна вносити та їх опрацьовувати.

Саме для вирішення останньої проблеми, яка $є$ найголовнішою, пропонується впровадити в рамках НАПН України електронну бібліотеку.

\section{ЗАГАЛЬНІ ПЕРЕДУМОВИ ПРОЕКТУВАННЯ ЕБ НАПН УКРАЇНИ}

1. У проектних рішеннях використовуються технології відкритих систем, відкриті мережеві протоколи, перспективні схеми і стандарти, що мають розвиток.

2. Усі проектні рішення мають бути типізовані й орієнтуватися на міжбібліотечну співпрацю й кооперацію відповідно до правил міжнародного інформаційного обміну.

3. У проекті необхідно максимально використовувати передовий досвід реалізації електронних бібліотек в інших організаціях у цілому або у вигляді окремих функціональних складових.

4. Проект ЕБ створюється за модульною схемою. Уся система ЕБ розбивається на модулі - підсистеми. Підсистеми виділяються за принципом функціональної спільності і подібності технологій. Такий принцип організації дозволяє розподілити проектування ЕБ між спеціалістами різного профілю, а згодом забезпечує можливість заміни окремих модулів або їх зміну з метою вдосконалення функціонала ЕБ або їі адаптації до нових умов. 
5. У проекті необхідно передбачити поетапне впровадження підсистем та їхніх функціональних складових, а також можливість масштабування, розвитку i доопрацювання рішень у кожній з наявних підсистем.

6. Технологічна інтеграція - єдність для всієї системи технології створення, оновлення, збереження і використання інформаційних ресурсів, зокрема, одноразове опрацювання документів поряд з багаторазовим і багатоцільовим їх використанням.

7. Корпоративність - дотримання принципів корпоративної взаємодії освітніх і наукових бібліотек і забезпечення органічного вбудовування ЕБ АПН України в інформаційно-освітнє середовище України.

8. Регламентованість усіх етапів функціонування ЕБ стандартами, маршрутними та поопераційними технологіями, нормативами на ресурсні та часові показники і т. п.

9. Пріоритет економічної доцільності - вибір таких проектних рішень, які за умови досягнення поставлених цілей і завдань забезпечують мінімізацію витрат фінансових, матеріальних і кадрових ресурсів.

10. Максимальне використання готових рішень для скорочення вартості $\mathrm{i}$ термінів розробки і впровадження, а також зменшення помилок проектування. Усі оригінальні розробки в функціоналі майбутньої системи пов'язані 3 інтеграцією і взаємодією готових блоків системи між собою.

11. Дотримання принципу спадкоємності - проект передбачається створювати на основі вже працюючого функціонала 3 максимально повним використанням наявних рішень.

\section{ІНФОРМАЦЙНІ РЕСУРСИ}

Одним з основних моментів функціонування ЕБ $є$ формування інформаційних ресурсів (IP). Інформаційні ресурси - це ядро ЕБ НАПН України. Інформаційні ресурси в окремих випадках формуються оцифровуванням існуючих документів на паперових носіях чи, як правило, використанням документів на магнітних носіях. Вихідні електронні документи можуть бути різних форматів, що представляють текстову інформацію, графічну, аудіо- і відеоінформацію.

Види електронних науково-освітніх ресурсів для формування і наповнення ЕБ НАПНУ:

1) наукові звіти; 
2) монографії ;

3) підручники;

4) посібники (навчальні,навчально-методичні, методичні);

5) методичні рекомендації;

6) словники, глосарії;

7) довідники,

8) програми навчальні;

9) концепції;

10) дисертації;

11) автореферати;

12) аналітичні записки;

13) статті;

14) книги;

15) лекції, тренінги, спецкурси;

16) програмно-методичні комплекси;

17) робочі зошити;

18) енциклопедії,

19) атласи;

20) стандарти;

21) буклети, брошури;

22) авторські свідоцтва, патенти;

23) навчально-методичні розробки;

24) збірники (тестові завдання, тренувальні тести);

25) тези та реферативні інформаційні матеріали;

26) науково-методичні та фахові журнали;

27) інформаційні бюлетені;

28) матеріали наукових конференцій, семінарів та круглих столів;

29) програмне забезпечення, яке знаходиться у вільному доступі;

30) мультимедійні, аудіо та відео програмні продукти навчального призначення.

Електронні ресурси установ НАПН України формуються в 2 етапи:

1 етап. Самоархівування. 
2 етап. Формування цифрового контенту.

Наповнення електронними ресурсами ЕБ НАПН України здійснюватиметься за принцами самоархівування та централізованого введення документів. Лише після того, як буде досягнуто $100 \%$ щорічного самоархівування власних наукових результатів організації, можна спрямовувати свої зусилля на інші цифрові цілі [2]. Процес формування контенту ЕБ буде відбуватися так.

Матеріали для опублікування в ЕБ НАПНУ, насамперед, повинні підготовлюватися авторами, за результатами квартальних та щорічних звітів, тобто всі ресурси, згідно вище наведеного переліку, повинні бути внесені до ЕБ НАПНУ в повнотекстовому вигляді. Такі матеріали самостійно депонуються автором або відповідальною особою, за принципами самоархівування. Загально інститутські поточні результати, вносяться до НАПУ розподілено або відповідальною особою.

ЕБ НАПНУ рекомендується створити відповідно до Ініціативи Відкритого Доступу (Open Archives Initiative) [11].

Централізоване введення документів. Тільки певний користувач або група користувачів, яка належать колективу, що використовує ЕБ, мають право вводити документи. Наприклад, якщо створюється ЕБ журналу, то таке право надається конкретній особі(ам) зі складу редакції журналу. Ніхто інший не має таких можливостей. Прикладом програмної системи зі створення ЕБ $з$ централізованим введенням є Greenstone (www.greenstone.org).

Відкрите введення документів. Це альтернативний варіант попередньому. Будь-яка людина може додати в ЕБ документ. У таких випадках, як правило, у складі служби експлуатації ЕБ $є$ фахівець (група фахівців), так званий редактор, відповідальний за перевірку якості і правильності оформлення введених документів. Усі введені документи обов'язково проходять редагування і тільки після їхнього схвалення редактором вони потрапляють в архів ЕБ. У випадку невідповідності прийнятим в ЕБ вимогам документи можуть бути повернуті відправнику на доопрацювання (наприклад, вони неправильно оформлені) або відхилені до прийому (наприклад, вони не відповідають тематичній спрямованості ЕБ). Прикладом програмної системи зі створення ЕБ з таким варіантом введення документів є Eprints (www.eprints.org). 
Розподілене введення документів. Як правило, використовується за наявності колекцій або деяких інших сукупностей документів. Для кожної колекції виділяється група осіб, які мають право введення. У цьому випадку редактор перевіряє коректність введених документів. Системи подібного роду найкраще підходять тоді, коли ЕБ створюється в організаціях зі складною ієрархічною структурою, наприклад у ВНЗ. Прикладом програмної системи зі створення ЕБ з таким варіантом введення документів є DSpace (www.dspace.org).

\section{ОРГАНІЗАЦІЙНІ ЗАСАДИ СТВОРЕННЯ ЕБ НАПН УКРАЇНИ}

Управління інформаційними ресурсами починається 3 того моменту, коли автор ресурсу направляє текст ресурсу і дані про нього в сховище (репозиторій). При цьому відбувається автоматична реєстрація ресурсу в системі, автоматичне індексування, і дані стають доступними для пошуку.

Підготовка й електронне опрацювання документів здійснюється авторами i редакторами ЕБ, які виділяються зі штату бібліотеки (установи), що бере участь у проекті. Проект планується втілювати централізовано, тобто на базі IITЗН будується єдине сховище, у якому виділяються робочі області колекцій для кожної з установ НАПН:

Інститут педагогіки;

Інститут психології ім. Г. С. Костюка;

Інститут спеціальної педагогіки НАПН України;

Інститут проблем виховання;

Інститут соціальної та політичної психології;

Інститут педагогічної освіти і освіти дорослих;

Інститут вищої освіти;

Інститут інформаційних технологій і засобів навчання;

Інститут професійно-технічної освіти;

Інститут обдарованої дитини;

Інститут спеціальної педагогіки;

Інститут соціальної та політичної психології НАПН України;

Державна науково-педагогічна бібліотека України ім. В. О.Сухомлинського; 
Науково-методичний центр «Українська етнопедагогіка i народознавство» НАПН України і Прикарпатського університету ім. В. Стефаника (м. ІваноФранківськ);

Львівський науково-практичний центр професійно-технічної освіти;

Кримський науково-методичний центр управління освітою (м. Сімферополь);

Науково-методичний центр інтеграції змісту освіти (м. Одеса);

ДВНЗ «Університет менеджменту освіти»;

Видавництво «Педагогічна преса»;

Педагогічний музей України.

Щоб уникнути проблем 3 дотриманням законодавства 3 авторського права, необхідною умовою є згода автора, який депонує свій ресурс до ЕБ, з умовами, на яких це ресурс буде публікуватися в ЕБ.

\section{Адміністрування бібліотеки}

Адміністрування - це центральна функція, що визначає ефективність ЕБ. До функцій адміністратора належить:

- встановлення конфігурації й налагодження ЕБ;

- забезпечення цілісності й безпеки ЕБ;

- надання користувачам прав доступу;

- аналіз роботи ЕБ і підтримка необхідної ефективності і якості функціонування ЕБ;

- включення ЕБ в інші інтеграційні системи інформаційного обслуговування користувачів.

\section{ОЧІКУВАНІ РЕЗУЛЬТАТИ}

Дослідний зразок програмного комплексу електронної бібліотеки матиме такі показники:

- чотирирівнева модель доступу до бібліотеки, включаючи анонімний вільний доступ;

- багатомовний інтерфейс;

- пошук по різноманітних полях метаданих та повнотекстовий пошук;

- навігація по електронній бібліотеці, яка буде відповідати європейській класифікації бібліотечних ресурсів щодо організації наукової діяльності;

- відповідність полів метаданих вимогам навчального процесу; 
- доступ до бібліотеки за допомогою мережі Інтернет;

- підтримка семантичного опису інформації на основі технології Semantic Web;

- підтримка протоколу обміну метаданими ОАІ-PMH;

- сервісно-орієнтований підхід;

- захищеність конфіденційної інформації або такої, що не підлягає розголошенню завдяки підтримки протоколу https.

Орієнтовні обсяги впровадження НДР визначаються такими показниками:

- експериментальний дослідний зразок програмного комплексу може бути використаний у 18 наукових і навчальних закладах НАПН України;

- орієнтовний обсяг інформації, що потенційно може бути опрацьований в експериментальній електронній бібліотеці, - понад 5 тисяч документів;

- орієнтовна кількість користувачів системи 3 боку НАПН України 1500 науковців, понад 7000 тих осіб, які навчаються;

- орієнтовна кількість читачів - до 10000 на рік.

Застосування технологій електронних бібліотек дозволить вирішити проблему збереження значних обсягів наукових відомостей, здійснити інтеграцію роз'єднаних інформаційних ресурсів, а також надасть можливість збереження раніше не збережених даних, що безповоротно втрачаються, (лабораторних журналів, фотографій, зображень, звуків та відеоінформації).

Будуть скорочені витрати на численне дублювання створюваних локальних баз даних і інформаційних систем. У результаті реалізації проекту буде розвинута наявна інфраструктура для генерації, організації, пошуку i передавання різнорідних електронних даних від інформаційних центрів-виробників до кінцевого користувача.

Електронна бібліотека НАПН України дозволить докорінно змінити сам принцип інформаційного обслуговування користувачів: звертаючись до системи, вони будуть одержувати не лише посилання (бібліографію чи реферат) на наявний електронний документ, але і сам документ (повну копію оригінальної статті, автореферат дисертації, графічний образ картини чи технічного креслення, відеозапис проведеного дослідження тощо).

Використання електронних бібліотек дозволить по-новому організувати робоче місце науковця шляхом реалізації можливості колективної роботи і навчання, 
створення колективних віртуальних середовищ. Крім того, це дозволить знизити вартість наукових досліджень за рахунок колективного використання інформаційних ресурсів.

Буде вирішена найважливіша соціально-політичне завдання адекватного подання багатої науково-педагогічної спадщини України у світовому інформаційному просторі.

\section{Список використаних джерел}

1. Батоврин В. К., Королёв А. С. Об автоматизации проектирования профилей открытых образовательных систем - Телематика'2003. Труды X Всероссийской научно-методической конференции (Санкт-Петербург, 14.04-17.04.2003). - СПб.: СПбГУ ИТМО, 2003. - 529 с.

2. Вопросы и ответы о самоархивировании [Электронный ресурс] // Веб-сайт "СОЦИОНЕТ". - 2000-2009. - Режим доступу: http://socionet.ru/docs/self-archivingFAQ-ru.htm\#33.DigitaLibidoo. - Заголовок з екрана.

3. ДСТУ 4249:2003 Інформаційні технології. Настанова щодо POSIX-сумісних середовищ відкритих систем (POSIX-OSE) (ISO/IEC TR 14252:1996. MOD). - K.: Госпотребстандарт, 2005. - 182 с.

4. Еременко B. T. Функциональная стандартизация протоколов информационного обмена в распределенных управляющих системах: автореф. дисс. д-ра техн. наук: 05.13.06 / Владимир Тарасович Еременко. - Орел: [б. и.] , 2005. - 31 с.

5 Задорожна H. T., Лавріщуева K. M. Менеджмент документообігу в інформаційних системах освіти (для ВНЗ і ППО): Навч.-метод. посіб. - К.: КП Видавництво «Педагогічна думка», 2007. - 227 с.

6. Захарова O. В., Захарова E. Г., Резніченко В. А. Каталог наукових електронних бібліотек в Інтернет. - Київ, 2005. - 76с.

7. Послання Президента України Віктора Януковича до Українського народу від 03.06.2010 [Електронний ресурс]. - Режим доступу: http://zakon.nau.ua/doc/?uid=1082.7104.0 - Заголовок з екрана.

8. Регейло I. Ю., Задорожна Н. Т., Базелюк О. В. Концепція Інтернет-порталу Національної Академії педагогічних наук України/ I. Ю. Регейло, Н. Т.Задорожна. [Електронний ресурс] // Інформаційні технології і засоби навчання: електронне 
наукове фахове видання. - 2010. - №3. - Режим доступу : http://www.ime.eduua.net/em17/emg.html. - Назва з екрана.

9. Розпорядження Кабінету Міністрів України від 27 серпня 2010 р. № 1723-p Про схвалення Концепції Державної цільової програми розвитку професійнотехнічної освіти на 2011-2015 роки [Електронний ресурс]. - Режим доступу: http://search.ligazakon.ua/1_doc2.nsf/link1/KR101723.html. - Заголовок з екрана

10. Cnipiн O. M. Проектування системи електронних бібліотек науковонавчальних закладів АПН України [Електронний ресурс] / О. М. Спірін, В. М. Саух, В. А. Резніченко, О. В. Новицький // Інформаційні технології і засоби навчання. - 2009. № 6(14). - Режим доступу до журн.: http://www.nbuv.gov.ua/ejournals/ITZN/em14/emg.html.

11. Open Archives Initiative [Електронний pecypc]. - Режим доступу: http://www.openarchives.org. - Заголовок з екрана.

\section{ПРОЕКТ КОНЦЕПЦИИ ЕЛЕКТРОННОЙ БИБЛИОТЕКИ НАЦИОНАЛЬНОЙ АКАДЕМИИ ПЕДАГОГИЧЕСКИХ НАУК УКРАИНЫ}

Спирин О. М., Иванова С. Н., Новццкий А. В., Шиненко Н. А.

\section{Аннотация}

В Концепции обосновывается актуальность создания электронной библиотеки (ЭБ) Национальной академии педагогических наук (НАПН) Украины, даются определения основных понятий и терминов, которые используются при исследовании, описываются основные направления формирования и развития ЭБ НАПН Украины. Сформулированы цели, принципы, задания, функции ЭБ. Определяются общие предпосылки проектирования ЭБ НАПН Украины, предоставляются ориентировочные исходящие данные. Дана классификация информационных ресурсов для ЭБ НАПН Украины и этапы их формирования. Описан процесс управления информационными ресурсами и администрирования ЭБ. Положения Концепции являются основой для разработки профиля ее комплектования, определения приоритетов при отборе изданий для перевода в электронную форму, решения технологических проблем.

Ключевые слова: электронная библиотека, Интернет, информационные ресурсы, информационные и коммуникационные технологи. 


\section{A PROJECT OF CONCEPTTION OF ELEKTRONIC LIBRARY OF NATIONAL ACADEMY OF PEDAGOGICAL SCIENCES OF UKRAINE}

\section{Spirin O., Ivanova S, Novickiy A., Shinenko N.}

\section{Resume}

Actuality of creation of electronic library (EL) of the National Academy of Pedagogical Sciences (NAPS) of Ukraine is grounded in the Conception, determinations of basic concepts and terms which are used for research are given, basic directions of forming and development of EL of NAPS of Ukraine are described. Aims, principles, tasks, functions of EL are formulated. General pre-conditions of planning of EL of NAPS of Ukraine are determined, reference outgoing information is given. Classification of information resources for EL of NAPS of Ukraine and the stages of their forming are given. There is described a process of management and administration of EL information resources. Positions of the Conception are bases for the development of type of its completing, determination of priorities at the selection of editions for the conversion into electronic form, decision of technological problems.

Keywords: electronic library, Internet, information resources, information and communication technologies. 